\title{
Use of School-Time Statistical Information for Students' Performance in Mathematical Sciences in Kwara State Technology Schooling Institutions
}

\author{
Joseph Bamidele Odeyemi
}

\begin{abstract}
This study determinedschool time statistics and performance indicators in mathematical science subjects. Four polytechnicswith one health institutions were used as case study. Six hundred and fifty seven students were selected. The institutions and students wereselected using purposive sampling method. Questionnaire was the main research instrument used to gather the necessary informationfrom the subjects. The study further investigated whether correlation exists between time factor and students' performance. Toaccomplish this, the scores in threemathematical science subjects and lecture times table were used. Data obtained through this means were analyzed by adopting descriptive statistics and correlation statistical tools. The analysis was done with the help of SPSS statisticalsoftware. The results of the research show that correlation exists between time factor and students' performance in all the threemathematical subjects. It was concluded that the various levels of school time have impact on student performance. Time for home workand assignment should be increased and classroom time should be used fully.
\end{abstract}

Index Terms- Correlation, Descriptive statistics, School time, Statistical information.

\section{INTRODUCTION}

Technology institutions are vocational and technical institutions established in Nigeria for self reliance. These institutions engaged in teaching, learning and research. The skills, knowledge acquired in science and engineering in these kinds of institutions are applied to real life situations. In order to achieve this school time are assigned to specific activities. There is class room time, there is instructional time, there is school free time, there is examination time, there are school days, there are non school days, and others.

School time statistical information is rarely found in the Ministry of Education (MOE), both state and federal. They are scarcely available with the supervising agencies such as, National Board for Technical Education (NBTE) and National University Commission. Aside from the general school duration fixed as a guide by the central government of Nigeria, states, schooling institutions fix their own school time. This explains the reason for variations in school time. School time vary from geo-political zone to geo-political zone, and state to state. Also, allocation of time to school activities varies from school to school, and one polytechnic to another polytechnic, in Kwara State. Statistical information are available in schools and polytechnic in the state but schooltime statistical information are scarcely found and rarelyused in these institutions.

It then becomes important that statistical information and indicators on and for these be provided since it is a driving force behind teaching, learning and students' performance. Among the determinants of students' performance is school time.

Joseph Bamidele Odeyemi, Department of Statistics, The Federal Polytechnic Offa, Kwara State, Nigeria
In Polytechnic, the role of statistical information in acquiringand developing technology and vocational skills cannot be played down. Statistical information is essential in the library, student enrolment, examinations and laboratory, for effective teaching and students' performance. For Polytechnic in Kwara State, they would need statistical information on total allocated teaching time, average instructional time, amount of school free time, average study time, average number of home work/assignment time, total learning time, proportion of student to allocated time, and total hours in a school day. Availability and useof this statistical information is very good for planning, decision making and performance.

Mathematical Science subjectsare crucial to any fields of study in the polytechnic.Mathematics is a core subject at the secondary level of education and a credit pass is made compulsory for entrance into tertiary institutions in Nigeria. It is also compulsory for students of polytechnics regardless of the course of study. Computer literacy is mandatory in all fields of study, and Statistics is applied in everyday life and every student in the polytechnic is taught statistics. These subjects require that students be focused. Experience has also shown that most students have little or no interest inMathematical Science subjects. Hence,statistical information on the length of school time utilized on the subjects should be known and determined.

According to Pope (2016) the various measures of time we have around us show that time is important to us (clocks, watches, cell phones, televisions, etc). He wrote that time is keeping track of when we are supposed to be where we are supposed to be and doing what we should be doing. In the polytechnicsector in Nigeria time factor has been an issue. It is an issue in the sense that scheduling time to activities and adhering to it has been a challenge to the students, teachers, and school administration. This is because some times the length of time used on an activity is related to the amount of achievement that one can attain. Palm Beach study time learning theory, 1864 states that "The more a student consume time while studying, the more accurately his/her retention of the materials studied, and the less his/her anxiety towards the test of examination". He concluded that study time is a function of students' achievement.

In this study measures of central tendency and measures of variations are some of the statistical information provided in this study. Thus, the study seeks to use descriptive statisticsand correlation to estimate performance indicators that can be used to measure the services provided by five technology institutions and its correlation with students' performance in the area of teaching and learning.

\section{AIMAND OBJECTIVES OF THE STUDY}

The aim of the study is to provide school-time statistical information as performance indicators in Mathematical 
Science subjects. The study intends to achieve the following objectives:

1. To find out the types of school time available and use in teaching and learning in technology institutions in Kwara State.

2. To determine the average school-time used in teaching and learning in each technology institutions in the State.

3. To determine the average weekly hours spent learning mathematical science subjects.

4. To ascertain correlation between school-time and students' performancein technology institutions in Kwara State.

5. To estimate the average test scores of students in each mathematical science subjects for every selected technology institutions.

\section{LITERATURE REVIEW}

Pope (2016) in the study of how the time of the day affects productivity in Mathematics and English revealed that morning class of Mathematics or English increases performance of students by GPA of 0.072 in the morning and GPA of 0.032 in the afternoon. Also discovered, is that a morning Mathematics class increases state test score to an equivalent of increasing teacher quality by one-fourth standard deviation and also equivalent to half of the gender gap. Therefore, indicating that the rescheduling of Mathematics in the morning can contribute to effective learning.

According to Mulenga and Mukuka (2016) pupils that study in the morning perform better than pupils that study in the afternoon. The reason given by them is because of the fact that pupils who study in the morning have a higher retentive memory than those that study in the afternoon.

Wile and Shouppe (2011) in their contribution on the research of the effect of time of teaching tried to answer the question: Does Time of the Day of Instruction have Impact on Class Achievement? In their findings the most effective time to teach students is the time preferred by the students. Carrell, Maghakian, and West (2011) considered the starting time of study in school setting. The research showed that starting school day 50 minutes after the normal starting time has a significant effect on achievement/performance of students. The significant positive effect is equivalent to raising teacher quality by one standard deviation.

Adeyemo (2005) in his own study concluded that students' academic achievement were the outcome of a combination of the study time behavior and other factors in any course of study. He specifically opined that study time attitude is an exercise that goes beyond merely reading for pleasure. Study time problems have to do with student's engagement in home work, assignments, reading and note taking, study period procedure, students' concentration in examination and teachers' consultancy services.

Palm Beach Community College (PBCC, 2008) in Ukpong\& George (2013) explained that study time can be used as a tool for estimating, and appraising as well as controlling learning outcomes behaviors. He added that academic achievement is a function of the time spent on a task needed to complete the task. Palm further reported that students in the recent times are spending less time studying than in the past.

\section{A. The Study Population}

The population studied comprises of students from Federal Polytechnic, Offa; Kwara State Polytechnic, Ilorin; Kwara State College of Health Technology, Offa; Igbo-Owu Polytechnic, Ilorin; and Lens Polytechnic, Offa. This list covered volunteers from federal and state (public), and private technology schooling institutions in kwara state.

\section{B. Sampleand Sampling Methods}

There are two levels of sampling in this study. First, the researcher used purposive sampling to select five institutions from the existing technological institutions. Second, the same purposive sampling was employed to select students from departments being taught mathematical science subjects in each of the institutions. The students are from diverse departments but majority of them are from statistics, computer science, and health information management departments. In all,1000 students collected the questionnaire but only 657 returned correctly filled questionnaire. The distribution of this shows that 192 comes from Federal Polytechnic, Offa; 251 comes from Kwara State Polytechnic, Ilorin; 92 comes from Kwara State College of Health Technology, Offa; 64 comes from Lens Polytechnic, Offa; and 58 comes from Igbo-Owu Polytechnic, Ilorin.

\section{Sourceof Data}

The source of data is both primary and secondary. It is primary in the sense that data were collected directly from the students through questionnaire. And secondary because existing lecture times table and test scores records were abstracted from institutions' records for selected students.

\section{Research Instruments and Data Collection}

The drafted questionnaire adapted for the study is mostly of Program for International Student Assessment (PISA), (Anderson; 1983). This is used to investigate time spent on different activity (both academic and non academic). Itemized in the questionnaire include teaching time, non teaching time, domestic activity time, and allocated teaching time. The data gathered through this were tabulated for each school and combined for analysis. The instruments used in this study for data collection are interviews and questionnaire. There are five facilitators. A facilitator for each selected institutions. Facilitators at the selected Institutions and research assistants were appointed trained/briefed for one day on how to complete the questionnaire. The questionnaires were administered to 1000 volunteered students of the selected technological institutions in Kwara state.

\section{E. Analysis of Data}

There are two categories of variables for the study. Variable $\mathrm{X}$ represents time while $\mathrm{Y}$ represents performance. The allocated teaching time per week in the different selected institutions was also gathered through the institutions so alsothe test scores. The collected data were tabulated. Theanalysis of the data was done and summarized using the following statistical tools and procedures: Descriptive statistics and Pearson Product Moment Correlation Pearson Product Moment Correlation Coefficient 


$$
r=\frac{n \sum x y-\sum x \sum y}{\sqrt{\left(n \sum x^{2}-\left(\sum x\right)\right)^{2}\left(n \sum y^{2}-\left(\sum y\right)\right)^{2}}}
$$

$-1<\mathrm{r}<1, \mathrm{x}=$ time spent, and $\mathrm{y}=$ student scores in a particular subject

\section{RESULTS AND DISCUSSION}

A. Measures of Central Tendency and Variation

Here, mean, range and standard deviations are estimated to show the expected time duration spent on activities and scores of students at the end.

\section{Test Score}

Table 1 shows test scores performance indicators in Mathematics, Statistics, and Computer Science for five technology institutions in Kwara State. These indicators are mean/average, range, and standard deviation, The minimum, maximum, variance, and other descriptive measures can be estimated from the table.

Table 1: Mean, Range and Standard Deviation of Test Scores

\begin{tabular}{|l|l|l|l|l|l|l|}
\hline Institution & $\begin{array}{l}\text { Mathematics } \\
\text { (mean score) }\end{array}$ & $\begin{array}{l}\text { Statistics } \\
\text { (mean score) }\end{array}$ & $\begin{array}{l}\text { Computer } \\
\text { Science (mean } \\
\text { score) }\end{array}$ & Mean & Range & $\begin{array}{l}\text { Standard } \\
\text { Deviation }\end{array}$ \\
\hline $\begin{array}{l}\text { Igbo-Owu } \\
\text { Polytechnic, } \\
\text { Ilorin }\end{array}$ & 59.95 & 63.95 & 63.37 & 62.42 & 4 & 2.1615 \\
\hline $\begin{array}{l}\text { Lens } \\
\text { Polytechnic, } \\
\text { Offa }\end{array}$ & 60.7 & 69.26 & 69.5 & 66.49 & 8.8 & 5.0128 \\
\hline $\begin{array}{l}\text { Kwara State } \\
\text { College of } \\
\begin{array}{l}\text { Health } \\
\text { Technology, } \\
\text { Offa }\end{array}\end{array}$ & 58.13 & 56.74 & 60.88 & 58.58 & 4.14 & 2.1069 \\
\hline $\begin{array}{l}\text { Kwara State } \\
\text { Polytechnic, } \\
\text { Ilorin }\end{array}$ & 60.93 & 59.58 & 65.99 & 62.17 & 6.41 & 3.3739 \\
\hline $\begin{array}{l}\text { Federal } \\
\text { Polytechnic, } \\
\text { Offa }\end{array}$ & 59.01 & 57.66 & 61.34 & 59.34 & 3.68 & 1.8616 \\
\hline Mean & 59.74 & 61.44 & 64.22 & & & \\
\hline Range & 12.8 & 12.52 & 8.62 & & & \\
\hline Std Dev & 1.1733 & 5.1791 & 3.5771 & & & \\
\hline
\end{tabular}

Of all the average scores the highest is $69.5 \%$ recorded in Computer Science from LensPolytechnic, Offa. The variability of the scores in Lens Polytechnic is also the highest.The range in the same Polytechnic is the highest as well.
2. Length of Learning Time

Table 2 is a dispersion and descriptive summary of the time spent in class room, self study/reading, home work/assignment and out-of normal class lesson /tutorial. All these are put as learning time in this study.

Table 2: Mean, Range and Standard Deviation of Learning Duration in a week

\begin{tabular}{|l|l|l|l|l|l|l|}
\hline Institution & $\begin{array}{l}\text { Mathematics } \\
\text { (mean score0 }\end{array}$ & $\begin{array}{l}\text { Statistics } \\
\text { (mean score) }\end{array}$ & $\begin{array}{l}\text { Computer } \\
\text { Science } \\
\text { (mean score) }\end{array}$ & Mean & Range & $\begin{array}{l}\text { Standard } \\
\text { Deviation }\end{array}$ \\
\hline $\begin{array}{l}\text { Igbo-Owu } \\
\text { Polytechnic, } \\
\text { Ilorin }\end{array}$ & 4.40 & 6.21 & 2.88 & 4.5 & 3.33 & 1.6671 \\
\hline $\begin{array}{l}\text { Lens } \\
\text { Polytechnic, } \\
\text { Offa }\end{array}$ & 7.47 & 7.41 & 6.75 & 7.21 & 0.72 & 0.3995 \\
\hline $\begin{array}{l}\text { Kwara State } \\
\text { College of } \\
\begin{array}{l}\text { Health } \\
\text { Technology, } \\
\text { Offa }\end{array}\end{array}$ & 3.87 & 6.35 & 5.76 & 5.33 & 2.48 & 1.2955 \\
\hline Kwara State & 7.14 & & & & & 1.73 \\
\hline
\end{tabular}


Use of School-Time Statistical Information for Students' Performance in Mathematical Sciences in Kwara State Technology Schooling Institutions

\begin{tabular}{|l|l|l|l|l|l|l|}
\hline $\begin{array}{l}\text { Polytechnic, } \\
\text { Ilorin }\end{array}$ & & & & & & \\
\hline $\begin{array}{l}\text { Federal } \\
\text { Polytechnic, } \\
\text { Offa }\end{array}$ & 4.91 & 9.89 & 8.69 & 7.83 & 4.98 & 2.599 \\
\hline Mean & 5.56 & 7.75 & 6.12 & & & \\
\hline Range & 3.6 & 3.68 & 5.81 & & & \\
\hline Std Dev & 1.6408 & 1.6032 & 3.1742 & & & \\
\hline
\end{tabular}

The highest average learning hours spent on mathematical science subjects is recorded in Statistics. Kwara State Polytechnic, Ilorinrecorded the highest average length of time per week on learning any of the three mathematical science subjects.
3. Length of Lessons and Tutorial Time

Table 3 depicts descriptive measures as well as variations in the duration of lessons and tutorial classes. Lessons and tutorial are very important for student to master whatever has been taught by the teacher in a formal class setting. Repetitions of skills bring perfection.

Table 3: Mean, Range and Standard Deviation of Lessons and Tutorial Duration in a week

\begin{tabular}{|c|c|c|c|c|c|c|}
\hline Institution & $\begin{array}{l}\text { Mathematics } \\
\text { (mean score) }\end{array}$ & $\begin{array}{l}\text { Statistics } \\
\text { (mean score) }\end{array}$ & $\begin{array}{l}\text { Computer } \\
\text { Science } \\
\text { (mean score) }\end{array}$ & Mean & Range & $\begin{array}{l}\text { Standard } \\
\text { Deviation }\end{array}$ \\
\hline $\begin{array}{l}\text { Igbo-Owu } \\
\text { Polytechnic, } \\
\text { Ilorin }\end{array}$ & 1.88 & 1.62 & 1.05 & 1.52 & 0.83 & 0.4345 \\
\hline $\begin{array}{l}\text { Lens } \\
\text { Polytechnic, } \\
\text { Offa }\end{array}$ & 2.5 & 1.69 & 2.75 & 2.31 & 1.06 & 0.5541 \\
\hline $\begin{array}{l}\text { Kwara State } \\
\text { College of } \\
\text { Health } \\
\text { Technology, } \\
\text { Offa }\end{array}$ & 1.35 & 2.35 & 1.13 & 1.61 & 1.22 & 0.6502 \\
\hline $\begin{array}{l}\text { Kwara State } \\
\text { Polytechnic, } \\
\text { Ilorin }\end{array}$ & 1.73 & 1.81 & 1.84 & 1.79 & 0.11 & 0.0569 \\
\hline $\begin{array}{l}\text { Federal } \\
\text { Polytechnic, } \\
\text { Offa }\end{array}$ & 1.76 & 1.72 & 1.97 & 1.82 & 0.25 & 0.1343 \\
\hline Mean & 1.84 & 1.84 & 1.75 & & & \\
\hline Range & 1.15 & 0.73 & 1.7 & & & \\
\hline Std Dev & 0.417 & 0.2942 & 0.6948 & & & \\
\hline
\end{tabular}

The range of learning hours spent in the three mathematical science subjects is 1 with the minimum of 7.75 hour. Lens Polytechnic, Offa spent the highest average length of time per week on lessons and tutorial.

4. Length of Home Work and Assignment Time
Table 4 shows the average and variation of the amount of time devoted to home work and assignment. Home work and assignment are very important in learning and understanding of technics involved in mathematical science subjects as it always reflects in students' performance.

The consequence is boldness in the examinations

Table 4: Mean, Range and Standard Deviation of Home Work and Assignment Duration in a week

\begin{tabular}{|c|c|c|c|c|c|c|}
\hline Institution & $\begin{array}{l}\text { Mathematics } \\
\text { (mean score) }\end{array}$ & $\begin{array}{l}\text { Statistics } \\
\text { (mean score) }\end{array}$ & $\begin{array}{l}\text { Computer } \\
\text { Science } \\
\text { (mean score) }\end{array}$ & Mean & Range & $\begin{array}{l}\text { Standard } \\
\text { Deviation }\end{array}$ \\
\hline $\begin{array}{l}\text { Igbo-Owu } \\
\text { Polytechnic, } \\
\text { Ilorin }\end{array}$ & 1.52 & 1.59 & 0.83 & 1.31 & 0.76 & 0.42 \\
\hline $\begin{array}{l}\text { Lens } \\
\text { Polytechnic, } \\
\text { Offa }\end{array}$ & 1.97 & 2.72 & 1 & 1.9 & 1.72 & 0.8623 \\
\hline $\begin{array}{l}\text { Kwara State } \\
\text { College of } \\
\text { Health } \\
\text { Technology, }\end{array}$ & 1.52 & 1 & 1.63 & 1.38 & 0.63 & 0.3365 \\
\hline
\end{tabular}




\begin{tabular}{|l|l|l|l|l|l|l|}
\hline Offa & & & & & & \\
\hline $\begin{array}{l}\text { Kwara State } \\
\text { Polytechnic, } \\
\text { Ilorin }\end{array}$ & 1.24 & 1.67 & 1.79 & 1.57 & 0.55 & 0.2892 \\
\hline $\begin{array}{l}\text { Federal } \\
\text { Polytechnic, } \\
\text { Offa }\end{array}$ & 1.01 & 3 & 1.53 & 1.85 & 1.99 & 1.0321 \\
\hline Mean & 1.45 & 2 & 2 & 1.35 & & \\
\hline Range & 0.96 & 2 & 0.96 & & & \\
\hline Std Dev & 0.3598 & 0.836 & 0.4175 & & & \\
\hline
\end{tabular}

Two hours is the highest average time spent on home work Table 5 gives the average amount of time spent out of the and assignment by the student per week. LensPolytechnic, allocated class room time expended on instructions. The Offa students spent much more time in home work and significant of this is that some students understand their assignment thanother institutions.

\section{Length of Instructional Time} teachers with a minimum amount of time. Others may not understand the same teacher until the teacher spends much more quality time teaching the same thing

Table 5: Mean, Range and Standard Deviation of Instructional Time (hours) in a week

\begin{tabular}{|c|c|c|c|c|c|c|}
\hline Institution & $\begin{array}{l}\text { Mathematics } \\
\text { Mean score) }\end{array}$ & $\begin{array}{l}\text { Statistics } \\
\text { (mean score) }\end{array}$ & $\begin{array}{l}\text { Computer } \\
\text { Science (mean } \\
\text { score) }\end{array}$ & Mean & Range & $\begin{array}{l}\text { Standard } \\
\text { Deviation }\end{array}$ \\
\hline $\begin{array}{l}\text { Igbo-Owu } \\
\text { Polytechnic, } \\
\text { Ilorin }\end{array}$ & 1 & 3 & 1 & 1.67 & 2 & 1.1547 \\
\hline $\begin{array}{l}\text { Lens } \\
\text { Polytechnic, } \\
\text { Offa }\end{array}$ & 3 & 3 & 3 & 3 & 0 & 0 \\
\hline $\begin{array}{l}\text { Kwara State } \\
\text { College of } \\
\text { Health } \\
\text { Technology, } \\
\text { Offa }\end{array}$ & 1 & 3 & 3 & 2.33 & 2 & 1.1547 \\
\hline $\begin{array}{l}\text { Kwara State } \\
\text { Polytechnic, } \\
\text { Ilorin }\end{array}$ & 4.17 & 5.37 & 4.88 & 4.81 & 1.2 & 0.6034 \\
\hline $\begin{array}{l}\text { Federal } \\
\text { Polytechnic, } \\
\text { Offa }\end{array}$ & 2.14 & 5.17 & 5.19 & 4.17 & 3.05 & 1.7552 \\
\hline Mean & 2.26 & 3.91 & 3.41 & & & \\
\hline Range & 3.17 & 2.37 & 4.19 & & & \\
\hline Std Dev & 1.3588 & 1.2453 & 1.6936 & & & \\
\hline
\end{tabular}

Highest average hour of instructions is recorded by Kwara society organization, computer usage, hobbies, and State Polytechnic, Ilorinin Statistics.

6. School Free Time

Itemized in table 6 are some activities which students spend their free time on. These activities are sleeping, commuting, religious activity, work for pay, family, watching TV, medication. The purpose of measuring student free time and finding out the way students spend their free time is that it may have a lot of implications on their studies. This may be positive or negative.

Table 6: Mean, Range and Standard Deviation of unscheduled Time in a week

\begin{tabular}{|l|l|l|l|l|l|l|l|l|}
\hline Activity & $\begin{array}{l}\text { Igbo-Owu } \\
\text { Polytechnic, } \\
\text { Ilorin } \\
\text { (mean score) }\end{array}$ & $\begin{array}{l}\text { Lens } \\
\text { Polytechnic, } \\
\text { Offa } \\
\text { (mean score) }\end{array}$ & $\begin{array}{l}\text { Kwara State } \\
\text { College of } \\
\text { Health } \\
\text { Technology, } \\
\text { Ilorin } \\
\text { (mean score) }\end{array}$ & $\begin{array}{l}\text { Kwara State } \\
\text { Polytechnic, } \\
\text { Ilorin } \\
\text { (mean } \\
\text { score) }\end{array}$ & $\begin{array}{l}\text { Federal } \\
\text { Polytechnic, } \\
\text { Offa } \\
\text { (mean } \\
\text { score) }\end{array}$ & Mean & Range & StdDev \\
\hline Sleeping & 7.03 & 6.67 & 6.61 & 6.28 & 6.81 & 6.68 & 0.75 & 0.2759 \\
\hline Commuting & 0.4 & 0.85 & 0.67 & 1.04 & 0.39 & 0.67 & 0.65 & 0.2831 \\
\hline Religious & 0.33 & 0.94 & 0.74 & 0.5 & 0.32 & 0.57 & 0.62 & 0.27 \\
\hline Work for pay & 0.06 & 0.43 & 0.2 & 0.15 & 0.21 & 0.21 & 0.37 & 0.1366 \\
\hline Family & 0.4 & 0.66 & 0.11 & 0.11 & 0.29 & 0.31 & 0.55 & 0.2296 \\
\hline Watching Tv & 0.24 & 0.54 & 0.27 & 0.34 & 0.19 & 0.32 & 0.35 & 0.1365 \\
\hline $\begin{array}{l}\text { Club/Society } \\
\text { org. }\end{array}$ & 0.07 & 1.01 & 0.35 & 0.09 & 0.11 & 0.33 & 0.94 & 0.3988 \\
\hline
\end{tabular}


Use of School-Time Statistical Information for Students' Performance in Mathematical Sciences in Kwara State Technology Schooling Institutions

\begin{tabular}{|l|l|l|l|l|l|l|l|l|}
\hline Hobbies & 0.32 & 0.41 & 0.3 & 0.28 & 0.08 & 0.28 & 0.33 & 0.1213 \\
\hline Medication & 0.02 & 0.2 & 0.08 & 0.11 & 0.04 & 0.09 & 0.18 & 0.0707 \\
\hline $\begin{array}{l}\text { Phone/ } \\
\begin{array}{l}\text { Computer } \\
\text { usage }\end{array}\end{array}$ & 0.91 & 1.71 & 0.97 & 1.28 & 1.09 & 1.19 & 0.8 & 0.3222 \\
\hline Mean & 0.98 & & & & & & \\
\hline Range & 7.01 & 1.34 & 1.03 & 1.02 & 0.95 & & & \\
\hline Std.Dev & 2.142 & 6.47 & 6.53 & 6.19 & 6.77 & & & \\
\hline
\end{tabular}

The maximum time spent is 6.68 and minimum is 0.07 recorded in sleeping andmedication activities respectively.

B. Correlation

Using scientific calculators and equation (1) the following were determined.

1. Determination of Correlation Between Test Scores and Learning Duration

Variable $\mathrm{x}$ is treated as learning time and $\mathrm{y}$ is treated as the test scores.

$\sum x=99.11$

$\sum x^{2}=710.4499$

$\sum y=926.99$

$\sum y^{2}=57502.3211$

$\sum x y=6133.2474$

$s_{x}=1.9933$

$s_{y}=3.9184$

$x=6.6073$

$\bar{y}=61.7993$

$r=0.076$

$n=15$

2. Determination of Correlation Between Test Scores and Lessons/Tutorial Duration. Variable $\mathrm{x}$ is treated as lessons/tutorial and $\mathrm{y}$ is treated as the test scores. $\sum x=27.15$

$\sum x^{2}=52.1433$

$\sum y=926.99$

$\sum y^{2}=57502.3211$

$\sum x y=1681.9197$

$s_{x}=0.463$

$s_{y}=3.9184$

$\bar{x}=1.81$

$\bar{y}=61.7993$

$r=0.1601$

$n=15$

3. Determination of Correlation Between Test Scores and Home Work and Assignment

Duration. Variable $\mathrm{x}$ is treated as home work and assignment time and $\mathrm{y}$ is treated as the testscores.

$$
\begin{aligned}
& \sum x=24.02 \\
& \sum x^{2}=43.6656 \\
& \sum y=926.99 \\
& \sum y^{2}=57502.3211 \\
& \sum x y=1486.804 \\
& s_{x}=0.6095 \\
& s_{y}=3.9184 \\
& -x=1.6013 \\
& - \\
& y=61.7993 \\
& r=0.5659 \\
& n=15
\end{aligned}
$$

4. Determination of Correlation Between Test Scores and Instructional Time Duration

Variable $\mathrm{x}$ is treated as instructional time and $\mathrm{y}$ is treated as the test scores. 
$\sum x=47.92$

$\sum x^{2}=185.2848$

$\sum y=926.99$

$\sum y^{2}=57502.3211$

$\sum x y=2960.7471$

$s_{x}=1.5165$

$s_{y}=3.9581$

$x=3.1947$

$\bar{y}=61.7993$

$r=0.011$

$n=15$

5. Determination of Correlation Between Test Scores and Free Time Duration. Variable $\mathrm{x}$ is treated as free time and $\mathrm{y}$ is treated as the test scores.

$\sum x=5.32$

$\sum x^{2}=5.7598$

$\sum y=926.99$

$\sum y^{2}=19253.2974$

$\sum x y=331.422$

$s_{x}=0.1576$

$s_{y}=2.8852$

$x=1.064$

$\bar{y}=62$

$r=0.8699$

$n=5$

\section{Test of Hypotheses}

The coefficients of correlation above are not absolutely zero but the values are small. To test whether these correlation are statistically significant the following hypotheses were postulated:

1. $H_{01}$ :There is no significant correlation between school non academic time and students' performance in the three mathematical science subjects.

2. $H_{02}$ : There is no significant correlation between Learning duration and students' performance in the three mathematical science subjects.

3. $H_{03}$ : There is no significant correlation between lesson time and students' performance in the three mathematical science subjects.

4. $\quad H_{04}$ : There is no significant correlation between home work time and students' performance in the three mathematical science subjects.

5. $H_{05}:$ There is no significant correlation between instructional time and students' performance in the three mathematical science subjects.

Table 7: Decision for Test of Correlation

\begin{tabular}{|l|l|l|l|}
\hline Hypothesis & $\begin{array}{l}\text { Coefficient of } \\
\text { Correlation, } r\end{array}$ & Critical value, r & Decision \\
\hline 01 & 0.8699 & 0.811 & Statistically significant \\
\hline 02 & 0.076 & 0.497 & $\begin{array}{l}\text { Not statistically } \\
\text { significant }\end{array}$ \\
\hline 03 & 0.1601 & 0.497 & $\begin{array}{l}\text { Not statistically } \\
\text { significant }\end{array}$ \\
\hline 04 & 0.5659 & 0.497 & Statistically significant \\
\hline 05 & 0.011 & 0.497 & $\begin{array}{l}\text { Not statistically } \\
\text { significant }\end{array}$ \\
\hline
\end{tabular}

Table 7 above shows the type and extent of relationship between school time and students' performance. Two of the correlation coefficients are statistically significant.

\section{CONCLUSION AND RECOMMENDATIONS}

The study shows the duration of time spent in both academic and non academic school time in five selected technology schooling institutions in Kwara state. It also shows the relationship between time used by students and students' performance. It shows that time spent freely by each student on the average is 1.06 hours on non scheduling activities per day. Of the activities measured 
in this respect sleeping took the highest with an average of 6.68 hours per day and medication took the least with an average of 0.09 hours per day. In addition, the study shows that school non-academic time used by the student has much role to play to the extent that its correlation with students' performance is 0.87 . This is found to be statistically significant. This may mean that it performs equally well or have the same implications as fixed school academic time. Thus, it can either mar or make good students' performance.

Of important is the role played by the time students spent on home work and assignment on student performance. This study shows that average time used by the students on home work and assignment is 1.6 hours per week on each of the mathematical science subjects. It has a correlation with students' performance of 0.57 . This correlation is statistically significant.

The average of the entire learning duration for each mathematical science subjects is determined to be 6.61 hours per week for each student. Its correlation with students' performance is 0.08 . Similarly, the average hour used by student in out-of-official-class-lecture lessons and tutorial is 1.81 hours for each subject per week. The correlation is 0.16 .The average instructional time used in the class is 3.19 hours for each subject. Its correlation with students' performance is 0.02 .

Finally, all the correlations are positive. This means that there exist a relationship between time and students' performance. Time (used and unused for learning) is not only one of the determinants but one of the factors of students' performance.

Students are hereby advised that equal treatment should be given the mathematical sciences as in other subjects that are not mathematically base. Students and teachers should be encouraged to spend much more time in learning mathematical sciences. One hour or less spent learning mathematical science subjects is only good for revision. Student should set/fixstudy time and adhere to it. Students should establish the amount of time it will take them to achieve a particular set outcome. Teachers should reduce time spent by students on non academic activities. Teachers and students should work more on home work and assignment. Students should adhere to 6 hours duration of sleep or rest per day. Allocated teaching time should be fully utilized for instructions. The different between allocated teaching time and instruction duration should be reduced to the minimum. Personal learning/study time should increase. School time statistical information should be used as students' performance indicators to measure the services provided in the institutions.

\section{ACKNOWLEDGMENT}

I am grateful to my employer, The Federal Polytechnic, Offa, Kwara State, Nigeria for the opportunity to participate in the Institution Based Research (IBR). My gratitude also goes to the sponsor of the research-Tertiary Education Trust Fund (TETFund), Nigeria. Thank you.

\section{REFERENCES}

[1]A. O. Adeyemo (2005). Test Anxiety, Recognitions, Study Habits and Academic Performance: A Perspective Study. Advances in Test Anxiety Research, 7,2,21-41

[2] L. Anderson (1983.) Instruction and Time on Task: A Review. Journal of Curriculum Studies, 13:289-303
[3] S. Carrell, T. Maghakian,. and J. E. West (2011). A's from Zzzz's? The Causal Effect of School Start Time on the Academic Achievement of Adolescents. American Economic Journal: Economic Policy $3: 62-81$.

[4] H. M. Mulenga andA. Mukuka. (2016).Learning Time of Day and Students' Academic Achievement at School Certificate Level; A Case Study of Chibote Girls'Secondary School. Journal of Education and Practice ISSN 2222-1735 (Paper)ISSN 2222-288X (Online). 7, 20.

[5] Palm Beach Community College (PBCC, 2008) Student Success; How to succeed in College and Still have time for your friends. College Journal,27, 3, 328-336

[6] N. G. Pope. (2016). How the Time of Day Affects Productivity: Evidence from SchoolSchedules. The Review of Economics and Statistics,March 2016, Vol. 98. doi:10.1162/REST_a_00525.

[7] D. E. Ukpong, I. N. George (2013).Length of Study Time Behaviours and Academic Achievement of Social Studies Education Students in the University of Uyo. InternationalEducation Studies, 6,3, 172-178

[8] A. J. Wile. and G. A. Shouppe (2011). Does Time-of-Day of Instruction Impact Class Achievement? Perspectives in Learning: A Journal ofthe College of Education \& Health Professions Columbus State University, 12, 1

Author's Profile

JOSEPH BAMIDELE ODEYEMI is a lecturer of Statistics in the Department of Statistics, Federal Polytechnic, Offa, Kwara State, Nigeria. He is a Statistician and Archivist. He has M.Sc.in Statistics from University of Ilorin, Nigeria. Also, he has Master in Archives and Records Management (MARM) from University of Ibadan, Nigeria. He is an author of many articles in international journal. He is a member of Nigerian Statistical Association and Professional Statistician of Nigeria. He is married blessed with children. 